\title{
In Vitro Anticancer Activity of Plant-Derived Cannabidiol on Prostate Cancer Cell Lines
}

\author{
Manju Sharma1", James B. Hudson², Hans Adomat1, Emma Guns', Michael E. Cox,3 \\ ${ }^{1}$ The Vancouver Prostate Centre, 2660 Oak St. Jack Bell Research Centre, Vancouver, Canada \\ ${ }^{2}$ Department of Pathology \& Laboratory Medicine, University of British Columbia, Vancouver, Canada \\ ${ }^{3}$ Department of Urologic Sciences, Faculty of Medicine, University of British Columbia, Vancouver, Canada \\ Email: ${ }^{*}$ msharma@prostatecentre.com, jbhudson@mail.ubc.ca, hadomat@prostatecentre.com, \\ eguns@prostatecentre.com, mcox@prostatecentre.com
}

Received 22 May 2014; revised 20 June 2014; accepted 3 July 2014

Copyright (C) 2014 by authors and Scientific Research Publishing Inc.

This work is licensed under the Creative Commons Attribution International License (CC BY).

http://creativecommons.org/licenses/by/4.0/

(c) (i) Open Access

\section{Abstract}

Cannabinoids, the active components of Cannabis sativa Linnaeus, have received renewed interest in recent years due to their diverse pharmacologic activities such as cell growth inhibition, anti-inflammatory effects and tumor regression, but their use in chemotherapy is limited by their psychotropic activity. To date, cannabinoids have been successfully used in the treatment of nausea and vomiting, two common side effects that accompany chemotherapy in cancer patients. Most non-THC plant cannabinoids e.g. cannabidiol and cannabigerol, seem to be devoid of psychotropic properties. However, the precise pathways through which these molecules produce an antitumor effect have not yet been fully characterized. We therefore investigated the antitumor and anti-inflammatory activities of cannabidiol (CBD) in human prostate cancer cell lines LNCaP, DU145, PC3, and assessed whether there is any advantage in using cannabis extracts enriched in cannabidiol and low in THC. Results obtained in a panel of prostate cancer cell lines clearly indicate that cannabidiol is a potent inhibitor of cancer cell growth, with significantly lower potency in non-cancer cells. The mRNA expression level of cannabinoid receptors CB1 and CB2, vascular endothelial growth factor (VEGF), PSA (prostate specific antigen) are significantly higher in human prostate cell lines. Treatment with Cannabis extract containing high CBD down regulates CB1, CB2, VEGF, PSA, pro-inflammatory cytokines/chemokine IL-6/IL-8. Our overall findings support the concept that cannabidiol, which lacks psychotropic activity, may possess anti-inflammatory property and down regulates both cannabinoid receptors, PSA, VEGF, IL-6 and IL-8. High CBD cannabis extracts are cytotoxic to androgen responsive LNCaP cells and may effectively inhibit spheroid formation in cancer stem cells. This activity may contribute to its anticancer and chemosensitizing effect against prostate cancer. Cannabidiol and other non-habit forming cannabinoids could be used as novel therapeutic agents for the treatment of prostate cancer.

\footnotetext{
*Corresponding author.
} 


\title{
Keywords
}

\author{
Prostate Cancer, Androgen Receptor, Cannabidiol (CBD), Anti-Inflammatory, CB1, CB2, Prostate \\ Cancer Cell Lines
}

\section{Introduction}

Prostate cancer is the most commonly diagnosed malignancy in men and the second leading cause of cancer death in males. Most early tumours are androgen-dependent, thus depriving the tumour of androgens via surgical or medical castration [1] has proven to have significant effects at the initial stages of prostate cancer. Despite the early efficacy of androgen ablation, advanced prostate cancer is resilient to such treatments and eventually relapses into a hormone refractory (androgen-independent) disease, with devastating results on morbidity and mortality rates [2]. There is currently no curative treatment against hormone refractory prostate cancer (HRPC). The most effective treatment regime for patients with HRPC, docetaxel-based chemotherapy, can only improve the median survival time by 3 months [3]. Therefore, effective treatment strategies against metastatic HRPC are urgently needed. The current therapies are not only successful in targeting differentiated tumor cells but also sparing the putative cancer stem/progenitor cells [4]. Similar to normal stem cells, cancer stem cells (CSCs) are thought to be quiescent compared with mature cancer cells [5]. This property makes CSCs resistant to chemotherapeutic drugs, which mainly target actively replicating cells. In addition, two recent studies demonstrated that prostate CSCs are androgen independent [6] and may not respond to hormone ablation as mature tumor cells do. Owing to their ability to self-renew and differentiate, CSCs are capable of regenerating the heterogeneous tumor population (with both androgen-dependent and androgen-independent cells) after hormone ablation, which accounts for tumor relapse. Therefore, elimination of the bulk of frequently replicating tumor cells as well as the rare subset of slow, dividing stem-like cells that are responsible for tumor regeneration may represent a better therapeutic strategy in the treatment of prostate cancer.

The therapeutic properties of the hemp plant, Cannabis sativa, have been known for many years, but the recreational use of its psychoactive effects has restricted its possible pharmaceutical application. In recent years cannabinoids and their derivatives have drawn renewed attention because of their diverse pharmacologic activities such as cell growth inhibition, anti-inflammatory effects, and tumor regression (Guzman et al. 2003) [7]. Cannabinoids have been shown to induce apoptosis in gliomas [8], PC-12 pheochromocytoma [9], CHP100 neuroblastoma [10], and hippocampal neurons [11] in vitro, and most interestingly, regression of C6-cell gliomas in vivo [12]. Plant-derived cannabinoids, especially cannabidiol, are shown to be potent inhibitors of prostate carcinoma both in vitro and in vivo [13]. Induction of apoptosis by cannabinoids in prostate and colon cancer cells may be phosphatase dependent [14]. Our case studies confirmed cannabinoid (CB) efficacy in reducing muscle spasticity in multiple sclerosis [15], pain levels over a 12-month period [16] and Cannabis responsive head injury induced multiple disabilities [17].

To date, cannabinoids have been successfully used in the treatment of nausea and vomiting [18], two common side effects that accompany chemotherapy in cancer patients. Nevertheless, the use of cannabinoids in oncology might be somehow underestimated since increasing evidence exist that plant, synthetic, and endogenous cannabinoids (endocannabinoids) are able to exert a growth inhibitory action on various cancer cell types. However, the precise pathways through which these molecules produce an antitumor effect has not been yet fully characterized, also because their mechanism of action appears to be dependent on the type of tumor cell under study. It has been reported that cannabinoids can act through different cellular mechanisms, e.g., by inducing apoptosis, cell-cycle arrest, or cell growth inhibition, but also by targeting angiogenesis and cell migration [7] [19]. Furthermore, the antitumor effects of plant, synthetic and endocannabinoids can be mediated by activation of either CB1 [20] or CB2 receptors or both [21] [22]. After the discovery of the two specific molecular targets for THC, CB1, and CB2 [23], it became clear that most of the effects of marijuana in the brain and peripheral tissues were due to activation of these two G-protein-coupled cannabinoid receptors. However, evidence is also accumulating that some pharmacological effects of marijuana are due to Cannabis components different from Tetrahydrocannabinol (THC). Indeed, C. sativa contains at least 400 chemical components, of which 66 have been identified to belong to the class of the cannabinoids [23]. The main limitation of the possible future use of THC in oncology 
might be represented by adverse effects principally at the level of the central nervous system, consisting mostly of perceptual abnormalities, occasionally hallucinations [24]. However, most non-THC plant cannabinoids seem to be devoid of direct psychotropic properties. In particular, it has been ascertained that cannabidiol is nonpsychotropic [25] [26] and may even mitigate THC psychoactivity by blocking its conversion to the more psychoactive 11-hydroxy-THC [27]. Moreover, it has been recently found that systematic variations in its constituents (i.e. cannabidiol and cannabichromene) do not affect the behavioral or neurophysiological responses to marijuana [28]. Finally, it has been also shown that, unlike THC, systemic administration to rats of cannabigerol does not provoke poly-spike discharges in the cortical electroencephalogram during wakefulness and behavioral depression [29]. These and other observations reinforce the concept that at least cannabidiol, cannabigerol, and cannabichromene lack psychotropic activity and indicate that for a promising medical profile in cancer therapy, research should focus on these compounds, which so far have been poorly studied with regard to their potential antitumor effects. By keeping this goal in mind, we decided to investigate the antitumor properties of plant cannabis. We screened two distinct chemically characterized Cannabis extracts (enriched in high cannabidiol and low THC), where the presence of nonpsychotropic cannabinoids along with THC has been reported to mitigate the potential side effects of the latter compound in clinical trials [27].

Despite research efforts, little is known about the prostatic cancer stem cells which were suggested to play an important role in tumor initiation, progression, and chemoresistance [6]. Because CSCs are believed to contribute to chemoresistance, we reasoned that the chemosensitizing effect of cannabis may be mediated through targeting of prostate CSCs. In this study, we show that cannabis extract treatment significantly down regulates protein expression of prostate CB1 and CB2. Meanwhile, Cannabis treatment not only suppresses the spheroid formation ability of prostate cancer cells but also down regulates pro-inflammatory cytokine IL-6 and chemokine IL-8, decreases secreted protein and mRNA expression of prostate-specific antigen and VEGF levels. Our overall findings support that cannabidiol (CBD) may possess anti-inflammatory, anti-CSC effects, and down regulate both cannabinoid receptors CB1 and CB2, leading to their anticancer and chemosensitizing effect against prostate cancer.

\section{Materials and Methods}

\subsection{Chemicals and Reagents}

Cannabinoid reference standards for THC, CBD and CBN were purchased from Sigma. For extractions, HPLC grade methanol, formic acid and acetonitrile were purchased from Fischer scientific. All reagents were at least of analytical grade. Stem cell reagent with supplements was purchased from Stem Cell technology, Vancouver. ELISA kits for PSA were purchased from (Roche Diagnostics PSA, Indianapolis, IN).

\subsection{Pre-Treatment of Cannabis Samples in the HPLC Method}

The cannabis extracts were kindly provided by Green Cross society of BC, Vancouver. Plant material samples were dried for $24 \mathrm{~h}$ in a $35^{\circ} \mathrm{C}$ forced ventilation oven. Crumbly samples were then ground and mixed. $200 \mathrm{mg}$ of this fine powder was weighed in a flask and extracted with $10 \mathrm{~mL}$ of a methanol by agitation during $30 \mathrm{~min}$. The extract was filtered and diluted hundred times with methanol for running on HPLC equipment. Under these conditions suitable chromatography is achieved for the three most abundant cannabinoids present in the samples.

\subsection{HPLC Equipment and Chromatographic Conditions}

Fifty samples of cannabis were analyzed by HPLC, out of which two were selected with high CBD and low THC. All chromatographic runs were carried out using a Waters 2695 HPLC with a 996 Photodiode array Detector. Full spectra were recorded in the range $228-300 \mathrm{~nm}$. Chromatographic separations were achieved using a Waters XTerra ${ }^{\circledR}$ MS C18 analytical column $(2.1 \times 150 \mathrm{~mm}$ column). Equipment control, data acquisition and integration were performed with Empower Pro 2.0 software. The mobile phase at $1 \mathrm{ml} / \mathrm{min}$. consisted of a mixture of water, Acetonitrile and $1 \%$ Formic acid. Initial setting was $55 \%$ acetonitrile (v/v), which was linearly increased to $85 \%$ acetonitrile over $30.5 \mathrm{~min}$, then increased to 95\% over next $2 \mathrm{~min}$ and $100 \%$ over next $0.5 \mathrm{~min}$. After maintaining this condition for $2.5 \mathrm{~min}$, the column was set to initial condition in $0.5 \mathrm{~min}$ and re-equilibrated to $55 \%$ for another $4.5 \mathrm{~min}$. The total runtime was $40 \mathrm{~min}$. Flow-rate was set to $0.3 \mathrm{ml} / \mathrm{min}$, the injection volume was $10 \mu \mathrm{l}$. All experiments were carried out at $30^{\circ} \mathrm{C}$. Calibration curves were run for a number of com- 
mercial standards (Sigma). Two cannabis extracts with high CBD and low THC were also run on 5890 series 11 Gas chromatograph from Hewlett Packard. Typical chromatograms with peaks showing THC, CBD and CBN are shown in Figures 1(a)-(c).

\subsection{Cell Lines and Culture Conditions}

LNCaP, DU145, PC3, BPH parental and PNT1B parental cells were obtained from American Type Culture Collection (Manassas, VA). PC3, DU145, BPH parental and PNT1B parental cells were cultured in DMEM supplemented with 5\% fetal bovine serum. LNCaP were maintained in RPMI 1640 medium (Invitrogen, Carlsbad, CA) supplemented with 5\% fetal bovine serum (Invitrogen). Primary cultures of human dermal fibroblasts (Lonza, Walkersville, MD, USA) were cultured in DMEM supplemented with $5 \%$ fetal bovine serum.All cell types were kept at $37^{\circ} \mathrm{C}$ in a $5 \% \mathrm{CO}_{2}$ environment.

\subsection{Treatment of Cells}

Cannabis (dissolved in DMSO), was used for the treatment of cells. For dose-dependent studies, cells were treated with cannabis at final concentrations of $0.5-7 \mu \mathrm{l} / \mathrm{ml}$ of medium (Figure 4 for concentration of THC,

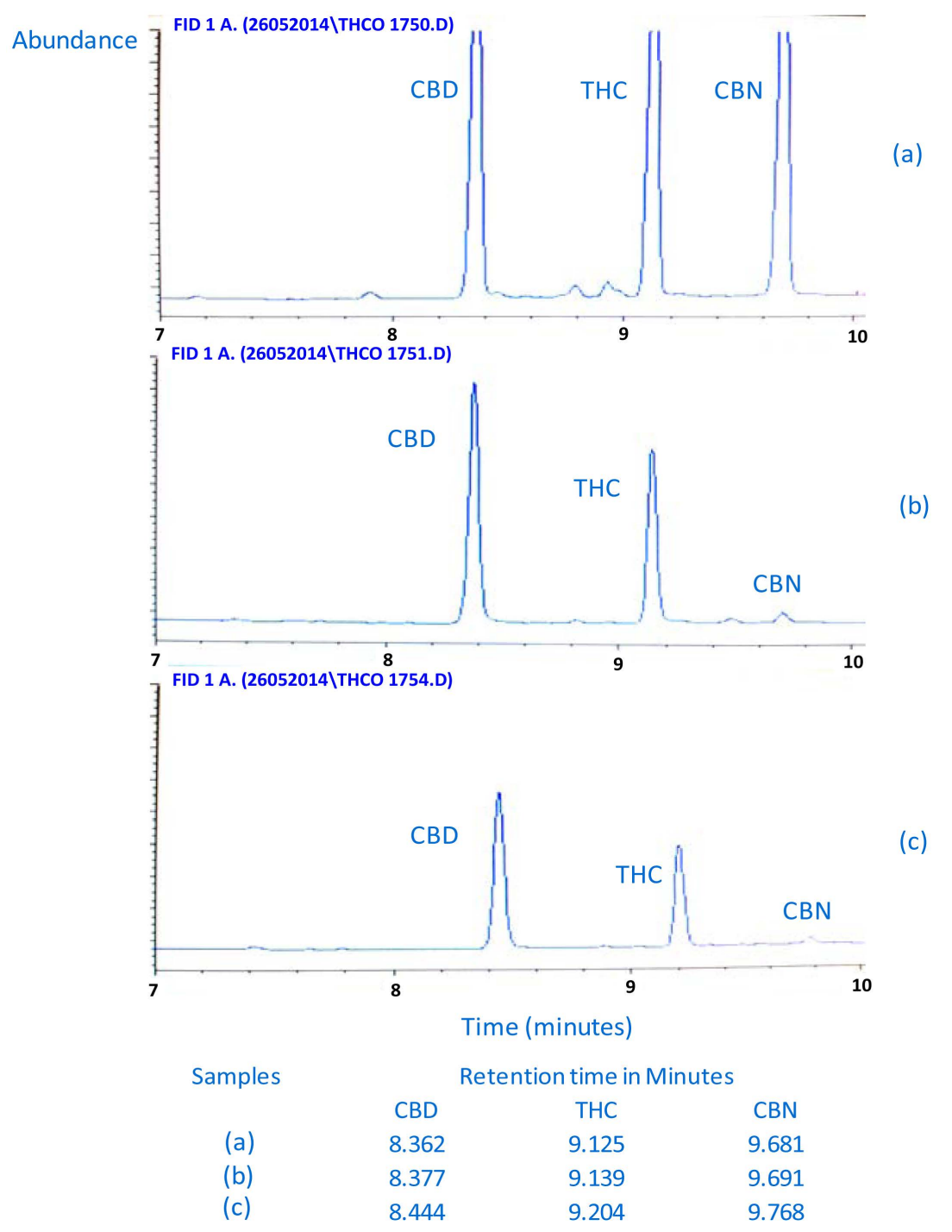

Figure 1. Example of chromatogram and retention times of the compounds (CBD, THC and CBN) (a) Standard, (b) and (c) Herbal cannabis samples. 
CBD and CBN in $\mu \mathrm{g} / \mu \mathrm{l})$. We also included a control treated with $0.5-7 \mu \mathrm{l} / \mathrm{ml}$ of DMSO. It was established that DMSO had no effect on the growth of the spheroids for 24 or 48 hours.

\subsection{Cell Viability Assay}

Cytotoxic profiles of high CBD extracts were assessed using the MTS ${ }^{\mathrm{TM}}$ [(3-(4, 5-dimethylthiazol-2-yl)-5(3-carboxymethoxyphenyl)-2-(4-sulfophenyl)-2Htetrazolium) and an electron coupling reagent (phenazinemethosulphate; PMS)] cell viability assay (Promega, Madison, WI, USA). Briefly, 5000 cells seeded in wells of 96 well plates (Corning, NY, USA) were allowed to attach overnight, exposed to 0.5 to $7.0 \mu \mathrm{l} / \mathrm{ml}$ cannabis extract for $24 \mathrm{~h}$. To make sure that the vehicle was not affecting cell functions, dimethyl sulfoxide (DMSO) (Sigma) was added to control experiments. The tetrazolium dye was added to each well of the plate and incubated for a further $4 \mathrm{~h}$. Optical density was then measured at $490 \mathrm{~nm}$ using a ELX 808 Automated Microplate Reader (Bio-TEK ${ }^{\circledR}$ Instruments, Winooski, VT, USA). All treatments were performed in triplicate. The percentage change in viable cell mass was presented as the $\mathrm{OD}_{490}$ ratio between the untreated and treated cells at the indicated concentrations.

\subsection{Lipopolysaccharide-Stimulated Cytokine-Related Factorprofiling}

Dermal fibroblasts were grown in 12 well plates (Corning) to produce confluent monolayers in DMEM. LPS was added to the culture media at $1 \mu \mathrm{g} / \mathrm{ml}$ for $24 \mathrm{~h} \pm 45$ or $20 \mu \mathrm{g} / \mathrm{ml}$ CBD cannabis extract. Conditioned media was harvested for ELISA tests. In data not shown, we observed that medium alone, with or without an equivalent volume of DMSO, and cell-free supernatant derived from control, uninfected cells exhibited indistinguishable levels of basal cytokine/chemokine production.

\subsection{Enzyme-Linked Immunosorbent Assays}

Sandwich ELISAs for IL-6 and IL-8 (RayBiotech, Norcross, GA, USA) were performed on culture supernatants from the indicated treatments according to manufacturer's instructions. Standard curve was constructed with supplied standards to allow conversion of $\mathrm{OD}_{450}$ absorbance readings of experimental samples to $\mathrm{pg} / \mathrm{ml}$. All samples were assayed in triplicate.

\subsection{Quantitative Real-Time PCR for mRNA Expression of CB1, CB2, PSA, AR and VEGF}

Total RNA was isolated from LNCaP cells using RNeasy kit according to the vendor's protocol. The ratio of optical densities of RNA samples at 260 and $280 \mathrm{~nm}$ was consistently $>1.8$. cDNA was synthesized using SuperScript First-Strand synthesis system for RT-PCR(Invitrogen). CB1/CB2 receptors, VEGF, AR and PSA were amplified using real-time PCR system ABI-PRISM 7900 (Applied Biosystems, Foster City, CA). Primers were designed as follows: CB1 receptor forward, 5'-CTCACAGCCATCGACAGGTA-3'; reverse, 5'-CGCAGGTCCTTACTCCTCAG-3'; CB2 receptorforward, 5'-TGCTCTGAGCTTTTCCCACT-3'; reverse, 5'-GGGCTTCTTCTTTTGCCTCT-3'. 18Srna forward, 5'-CGATGCTCTTAGCTGAGTGT-3'; reverse, 5'-GGTCCAAGAATTTCACCTCT-3'; VEGF, forward, 5'-TCTTCAAGCCATCCTGTGTG-3; and reverse, 5'-ATCTGCATGGTGATGTTGGA-3'. Androgen receptor (AR) forward, 5'-AAGACGCTTCTACCAGCTCACCAA; reverse, 5'-TCCCAGAAAGGATCTTGGGCACTT; PSA forward, 5'-ACTCACAGCAAGGATGGAGCTGAA; reverse, 5'-TGAGGGTTGTCTGGAGGACTTCAA.

The cycler was programmed with the following conditions: a) initial denaturation at $94^{\circ} \mathrm{C}$ for 2 minutes, followed by 35 cycles of b) $94^{\circ} \mathrm{C}$ for 40 seconds; c) annealing of the primer template at $58^{\circ} \mathrm{C}$ for 40 seconds; and d) extension at $72^{\circ} \mathrm{C}$ for 40 seconds. Target gene expression was normalized to 18Srna levels in respective samples as an internal standard and relative transcript quantity was calculated using the $\Delta \Delta \mathrm{Ct}$ method of Applied Biosystems [30]. Each assay was performed in triplicate.

The calculating equation for $\Delta \Delta \mathrm{Ct}$ is as follows:

$$
\begin{aligned}
& \text { Fold change }=2_{T}^{-\Delta \Delta C} \\
& \begin{aligned}
2_{T}^{-\Delta \Delta C}= & {[(\text { CT gene of interest }- \text { CT internal control }) \text { sample A }} \\
& -(\text { CT gene of interest }- \text { CT internal control }) \text { sample B }]
\end{aligned}
\end{aligned}
$$




\subsection{ELISA for PSA}

The human PSA ELISA kit was used for the quantitative determination of PSA levels in culture medium on a Cobas e 411 immunoassay analyzer (Roche Diagnostics PSA, Indianapolis, IN), according to the manufacturer's instruction. This kit uses a technique of quantitative sandwich immunoassay for determination of PSA with an estimated sensitivity of $1 \mathrm{ng} / \mathrm{ml}$ PSA antigen.

\subsection{Quantification of Apoptosis by Flow Cytometry}

The cells were grown at density of $1 \times 10^{6}$ cells in $100 \mathrm{~mm}$ culture dishes and were treated with Cannabis extract $(0.5-7 \mu \mathrm{l} / \mathrm{ml})$ for 24 hours. The cells were trypsinized, washed with PBS and fixed with ice cold $70 \%$ ethanol. Cells were subsequently stained with a propidiumiodide (PI) staining buffer $(0.1 \mathrm{mg} / \mathrm{ml}$ RNase A, $0.05 \%$ Triton-X-100 and $50 \mu \mathrm{g} / \mathrm{ml}$ of PI in PBS) for 1 hour. Samples were analyzed by flow cytometer and BD FACSDiva Software.

\subsection{Spheroid Formation Assay}

Briefly, cells were trypsinized, washed with 1\% PBS and re-suspended in DMEM with 5\% FBS. Five hundred cells were added to each well of a 6-well plate (Ultra low Cluster plate, Corning NY 14831). Cells were grown in Stem cell medium with proliferation medium supplemented with heparin and hydrocortisone from Stem cell Technology, Vancouver. Fresh medium with the above supplements was added every week. Cannabis extract (20 $\mu \mathrm{g} / \mu \mathrm{l}-60 \mu \mathrm{g} / \mu \mathrm{l} \mathrm{CBD}$ ) was added to the medium and the number of spheroids was counted at the Day 14 of the assay. Each experiment was repeated in triplicate, and each data point represents the mean and SD.

\subsection{Statistical Analysis}

MTS assay: Differences in cell viability, expressed as the OD ratio between treated and untreated cells at the indicated concentrations, were calculated using a Student's two-tailed t-test assuming equal variances.

Enzyme-linked immunosorbent assays: Results were compared using a one-way analysis of variance followed by a Bonferroni post-test comparing only the pairs of interest. All analysis of variance p-values were significant, and the post-test results are shown in the respective tables.

\section{Results}

\subsection{Expression of Cannabinoid Receptors in Normal and Prostate Cancer Cells}

We first compared the expression levelsof both cannabinoid receptors CB1 and CB2 in Prostate epithelial cells (PrEC) and a series of human prostate cancer cells. The data shown in Figure 2 revealed that expression of both CB1 and CB2 receptors was significantly higher in prostate cancer cells, CB1, 23 fold for LNCap, 90 fold for DUI45, 570 fold for PC3 as compared with normal prostate cells BPH1 and PNT1B PrEC cells (Figure 2(a)). CB1 for LNCaP was further upregulated by 841 fold when stimulated with androgen R1881 (Figure 2(b)). CB2, 105.8 fold for LNCap, 45 fold for DUI45, 71 fold for PC3 as compared with normal PrEC cells (Figure 2(c)). CB2 for LNCaP was further upregulated by 1683 fold when stimulated with androgen R1881 (Figure 2(d)).

\subsection{Effect of Cannabis Extract on Cell Viability of PrEC (BPH and PNT1B), LNCaP and PC3 Cells}

To evaluate the cell viability response of cannabis extract on PrEC, LNCaP and DU145 cells, MTS assay was employed. Data in Figure 3(a) \& Figure 3(b) show that treatment of PrEC cells with cannabis extract (20 - 80 $\mu \mathrm{g} / \mathrm{ml} \mathrm{CBD}$ ) for 24 hours had no effect on cell viability. However, treatment of LNCaP and PC3 cells with similar doses of cannabis extract in a dose-dependent manner significantly decreased the viability at 24 hours (Figure 3(c) \& Figure 3(d)).

\subsection{CB1 and CB2 Receptor Activation Signals Growth Inhibition in LNCaP Cells}

To study the possible implication of CB1 and CB2 receptors in cannabis extract-induced cell death, mRNA expression of the two receptors were quantified by real time PCR. Treatment of LNCaP cells with cannabis extract 


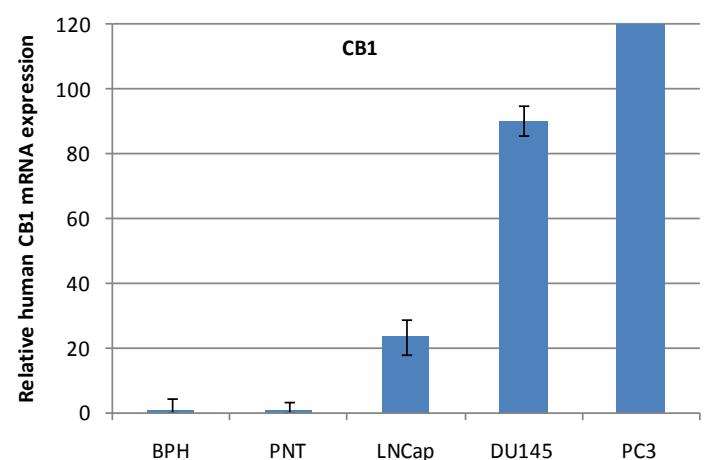

(a)

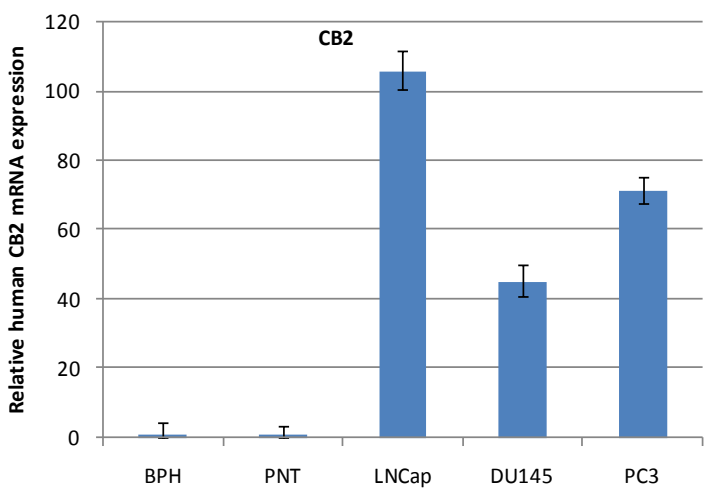

(c)

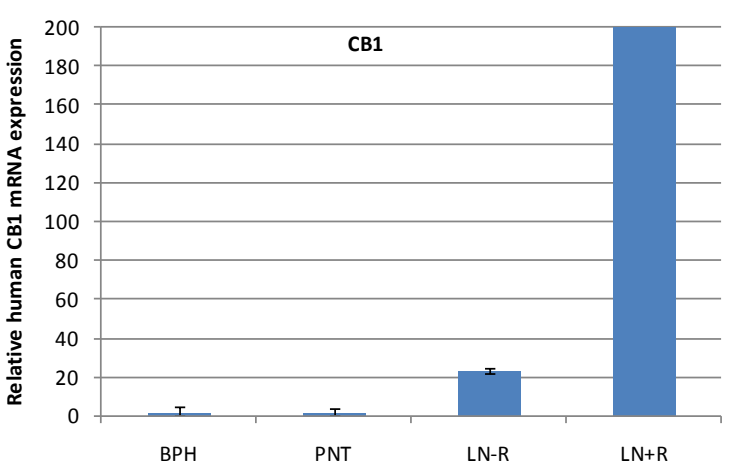

(b)

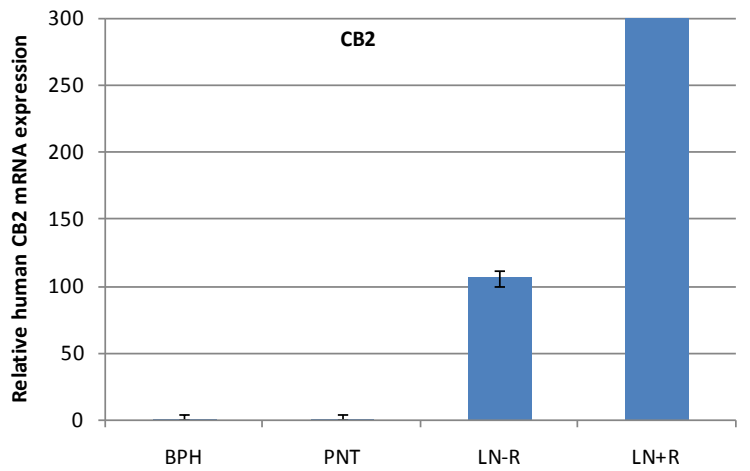

(d)

Figure 2. CB1 \& CB2 Expression are increased in Prostate cancer cells. Expression of CB1 and CB2 in human prostate epithelial cells and prostate cancer cells. mRNA expression of CB1 and CB2 was determined in androgen dependent LNCaP with and without R1881, androgen independent DU145 and PC3 prostate cancer cell lines. Expression of CB1 and CB2 mRNA was up regulated in PCa cell lines as compared to BPH1 and PNT1B prostate epithelial cell lines.

(20 - $70 \mu \mathrm{g} / \mathrm{mlCBD}$ ) for 24H down regulated expression of CB1 and CB2.

These data suggest that both CB1 and CB2 receptors may be involved in cannabis extract mediated growth inhibition and apoptosis (Figure 4(a) \& Figure 4(b)).

\subsection{Effect of Cannabis Extract on Androgen Receptor and PSA in LNCaPCells}

Androgens are involved in the development and progression of prostate cancer where androgen receptor is assumed to be the essential mediator for androgen action. In the next series of experiments, we determined the effect of cannabis extract on mRNA expression of androgen receptor. In a dose-dependent study, we found that treatment of LNCaP cells with cannabis extract resulted in a marked decrease in androgen receptor expression (Figure 5(a)). Studies have also shown that modulation in androgen receptor leads to alteration in androgen-responsive genes [31]. PSA is an androgen-responsive gene and is regarded as the most sensitive biomarker and screening tool for prostate cancer in humans [32]. The dose-dependent effect of cannabis extract on LNCaP cells showed a significant decrease in PSA mRNA expression at 20, 40, 60 and $70 \mu \mathrm{g} / \mathrm{ml}$ CBD concentration when assessing at 24 hours post-treatment (Figure 5(c)). We next examined the effect of cannabis extract on secreted levels of PSA in LNCaP cells. Employing ELISA technique, we found that treatment of LNCaP cells with cannabis extract resulted in a dose-dependent decrease in the secreted levels of PSA by 57.9\%, 49\%, 33.5\%, 24.9\% and $17.1 \%$ at 20, 40, 60 and $70 \mu \mathrm{g} / \mathrm{ml} \mathrm{CBD}$ concentrations, respectively (Figure 5(d)). From these data, it seems that the decrease in LNCaP cell growth was concomitant with a decrease in androgen receptor mRNA expression as well as a decrease in secreted PSA level.

\subsection{Effect of Cannabidiol on VEGF}

Because VEGF is a marker for angiogenesis, blocking the angiogenic process may represent a promising way of 
MTS Assay : BPH1

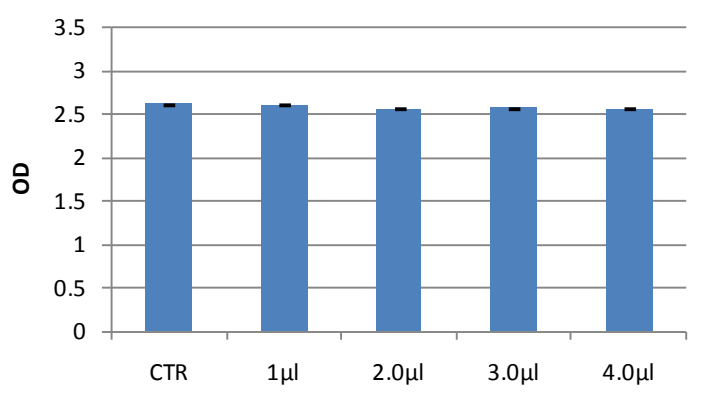

(a)

MTS Assay: LNCaP

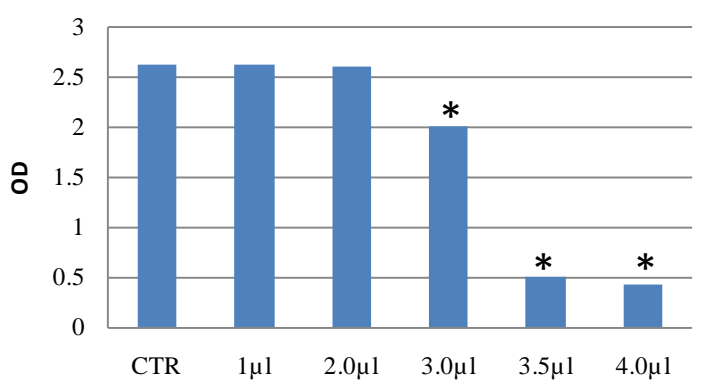

$\begin{array}{ccccccc}\text { CBD } & 0 & 20 & 40 & 60 & 70 & 80 \\ \text { CBN } & 0 & 0.4 & 0.8 & 1.2 & 14 & 1.4 \\ \text { THC } & 0 & 10 & 20 & 30 & 3.5 & 40\end{array}$

(c)

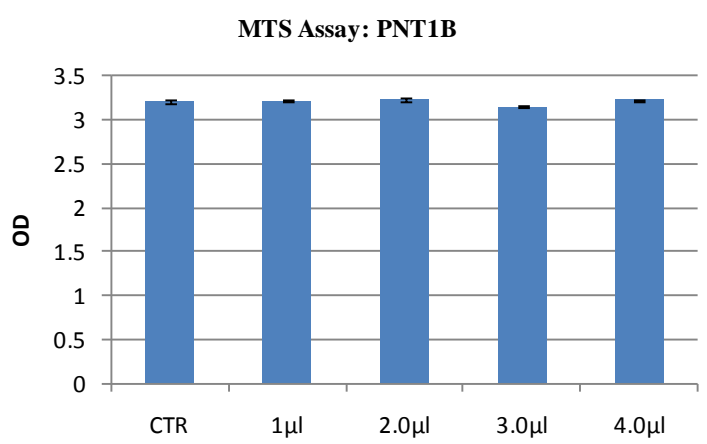

(b)

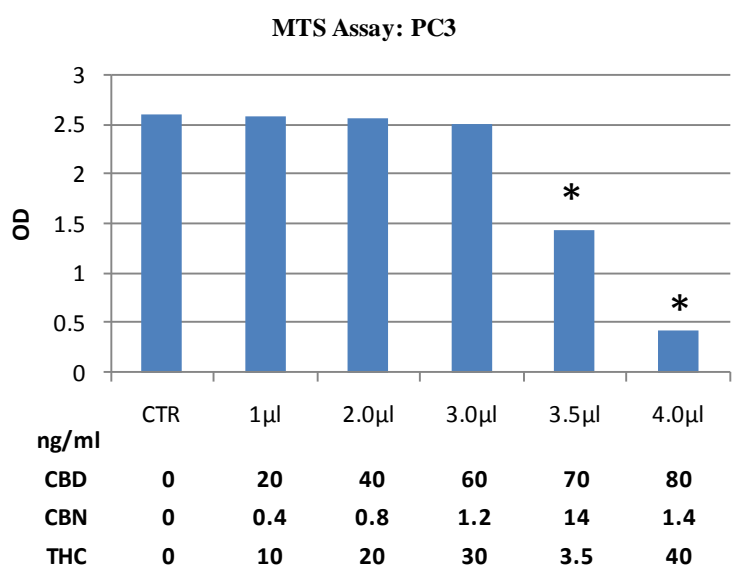

(d)

Figure 3. Cannabinoids are selectively cytotoxic to PCa. Effect of cannabis extract on cell viability: A, and B, effects on the viability of PrECs A \& B, LNCaP (c) and PC3 (d). As detailed in Materials and Methods, the cells were treated with cannabis extract in different doses for 24 hours, and their viability was determined by MTS assay. Columns, means; bars, \pm SE of three separate experiments; ${ }^{*} \mathrm{P}<0.001$ compared with control (0 CBD).

RQ CB1

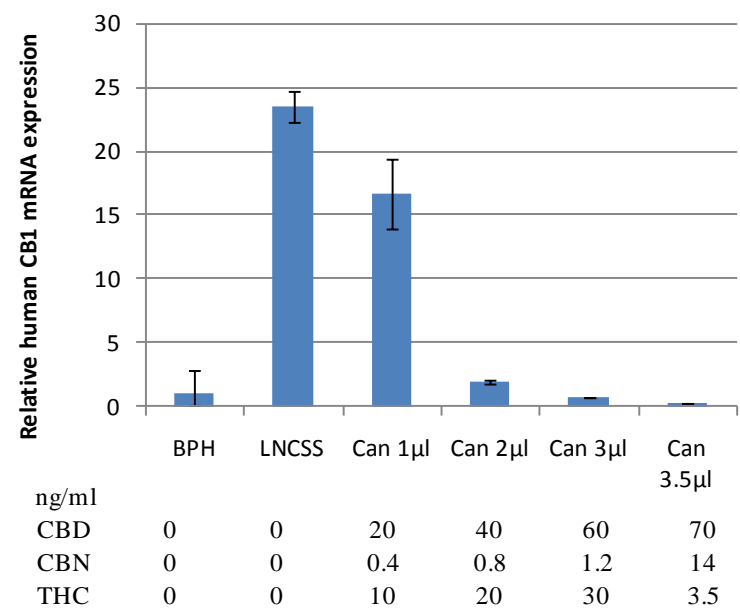

(a)
RQ CB2

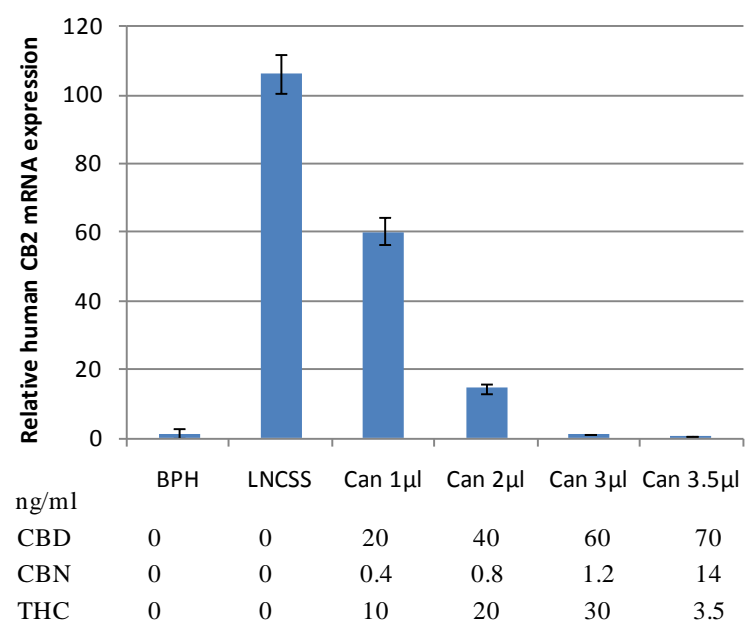

(b)

Figure 4. Evidence for cytopathic effects of cannabinoids on PCa cell lines. Effect of cannabis extract on mRNA expression of cannabinoid receptors CB1 and CB2 in human prostate epithelial cells and prostate cancer cells. Dose dependent effect of cannabis extract on mRNA expression of CB1 and CB2 was determined in LNCaP cells by quantitative real time-PCR from representative experiments repeated thrice with similar results. Relative levels of expression normalized to the mRNA level of 18 Srna. The fold change in LNCaP cells were compared with PrEC. 
RQ AR

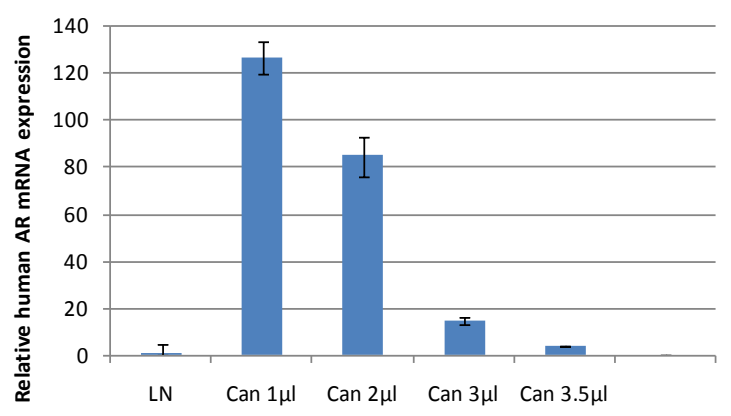

(a)

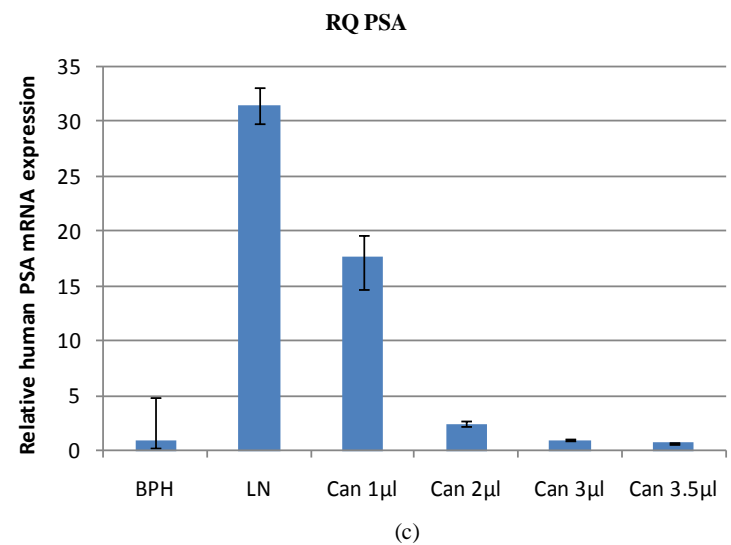

RQ VEGF

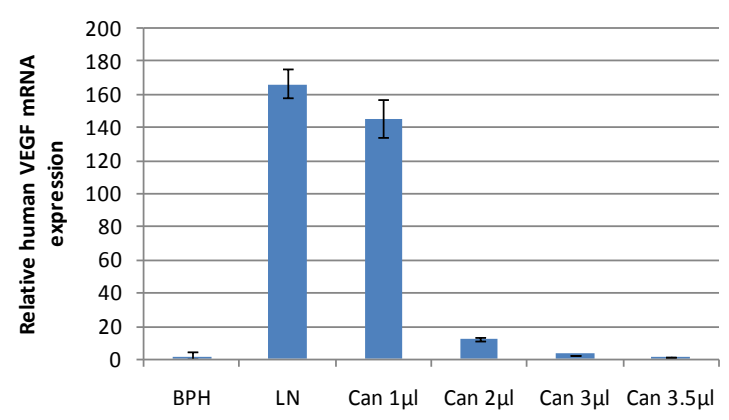

(b)

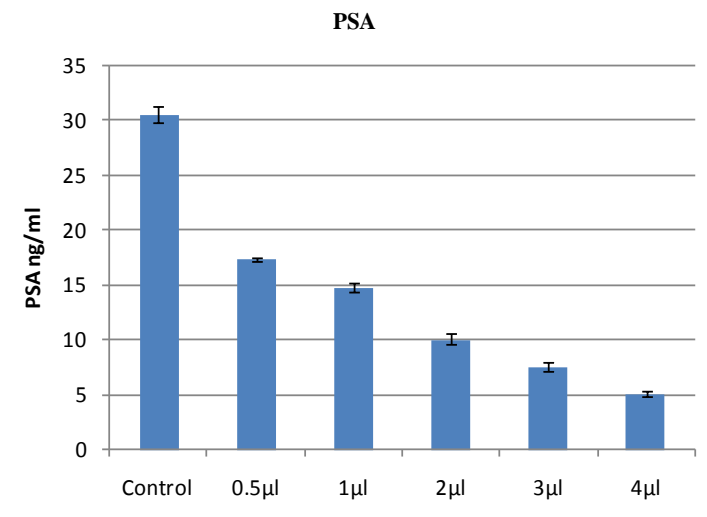

(d)

Figure 5. Evidence for cytopathic effects of cannabinoids on PCa cell lines. Effect of cannabis extract on mRNA expression of androgen receptor,VEGF and PSA in LNCaP cells. As detailed in Materials and Methods, the cells were treated with DMSO alone or with specified concentrations of cannabis extract in DMSO and then harvested. Dose dependent effect of cannabis extract on mRNA expression of androgen receptor (a), VEGF (b) and PSA (c) in LNCaP cells was determined by quantitative real time-PCR from representative experiments repeated thrice with similar results. (d) Effect on secreted levels of PSA. Cells were treated with different doses of cannabis extract for 24 hours and then harvested. The PSA levels were determined by ELISA as described under Materials and Methods.

treating the tumor. Studies have shown that androgen regulates VEGF content in prostate cancer [33]. As cannabis extract treatment resulted in a decrease in androgen receptor expression, the effects on VEGF were also determined. It was observed that cannabis extract treatment resulted in a dose dependent decrease in VEGF mRNA expression (Figure 5(b)).

\subsection{Effect of Cannabis Extract on Apoptosis of LNCaP Cells}

We next assessed whether the cell growth inhibitory effect of cannabis extract was associated with induction of apoptosis. We quantified the extent of apoptosis by flowcytometric analysis of the cells labeled with Propidium iodide (PI). LNCaP cells were treated with cannabis extract $(20-60 \mu \mathrm{g} / \mathrm{ml} \mathrm{CBD,} 10$ - $30 \mu \mathrm{g} / \mathrm{ml}$ THC and 0.4 $12 \mu \mathrm{g} / \mathrm{ml}$ CBN) for 24 hours. As shown by the data in Figure 6(a), cannabis extract treatment of LNCaP cells resulted in $10.1 \%, 25 \%$ and $42 \%$ of apoptotic cells at a dose of 20,40 and $60 \mu \mathrm{g} / \mathrm{ml}$ CBD respectively. Whereas the induction of apoptosis was almost negligible at the lowest dose (20 $\mu \mathrm{g} / \mathrm{ml} \mathrm{CBD)} \mathrm{used,} \mathrm{the} \mathrm{highest} \mathrm{dose} \mathrm{em-}$ ployed $(60 \mu \mathrm{g} / \mathrm{ml} \mathrm{CBD})$ resulted in a massive induction of apoptosis. Cannabis extract treatment of PC3 cells resulted in 21\%, 21\% and 39.4\% of apoptotic cells at a dose of 20, 40 and $60 \mu \mathrm{g} / \mathrm{ml}$ CBD respectively (Figure 6(b)). Both LNCaP and PC3 showed G0/G1 cell cycle arrest of cells at 40 and $60 \mu \mathrm{g} / \mathrm{ml} \mathrm{CBD} \mathrm{treatment.}$

\subsection{Anti-Inflammatory Properties of High CBD Cannabis Extract on Dermal Fibroblasts}

Prior to assessing anti-inflammatory properties of the cannabis extract, the ability of LPS to induce secretion of key cytokine-related factors (IL-6 and IL-8,) was assessed in dermal fibroblast cultures. After $24 \mathrm{~h}$ of LPS 
DNA Cell Cycle LNCaP

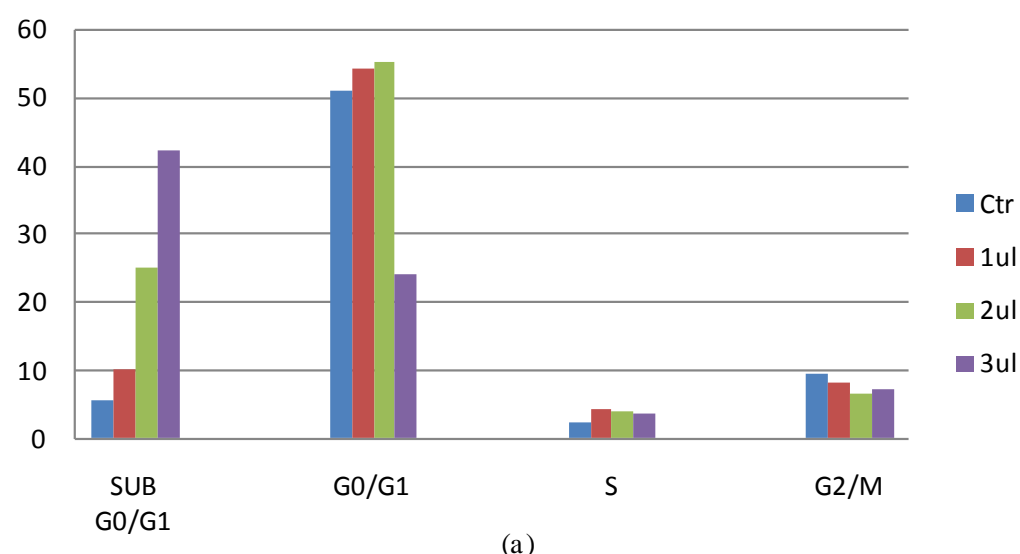

DNA Cell cycle PC3

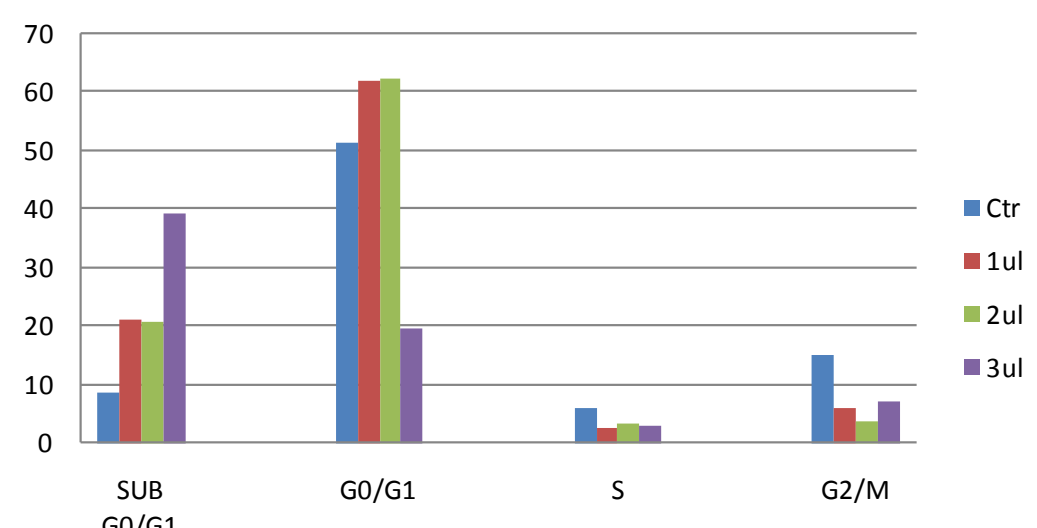

(b)

Figure 6. Quantification of apoptosis by Flow Cytometry. Effect of cannabis extract on apoptosis in LNCaP cells. (a) and (b) Quantification of apoptosis in LNCaP and PC3 cells by flow cytometry. The cells were treated with cannabis extract $(20 \mu \mathrm{g} / \mathrm{ml}$ of CBD) for 24 hours. The cells were trypsinized, washed with PBS and fixed with ice cold $70 \%$ ethanol. Cells were subsequently stained with a propidium iodide (PI) for 1 hour. Samples were analyzed by flow cytometer and BD FACS Diva Software and apoptosis rate in PCa cell lines were calculated as the percentage of cells in sub G0/G1 and Go/G1 phase. Data from representative experiments repeated thrice with similar results.

stimulation, dermal fibroblast conditioned media contained substantially elevated levels of IL-6 and IL-8 (Figure 7(a) \& Figure 7(b)). As an assessment of potential anti-inflammatory properties of cannabis extract, we observed that accumulation of the indicated cytokines in conditioned media of the LNCaP cells was significantly suppressed by $20 \mu \mathrm{g} / \mathrm{ml} \mathrm{CBD}$ cannabis extract treatment. MTS assays performed on LNCaP cells at the end of the experiment indicated that none of the LPS or cannabis extract treatment combinations affected cell viability relative to vehicle controls (data not shown). Additional control tests showed that the cannabis extract did not interfere significantly in any of the ELISA steps.

\subsection{Cannabidiol Inhibits Prostasphere Formation of LNCaP Cells under Non-Adherent Culture Conditions}

The ability to form prostaspheres in non-adherent culture is one of the characteristics of prostate CSCs (Reynolds et al. 1992) [34]. To confirm that cannabis extract treatment can inhibit prostate CSC properties, prostasphere formation of LNCaP cells was studied in the presence or absence of cannabis extract. 500 hundred LNCaP 
IL- 8

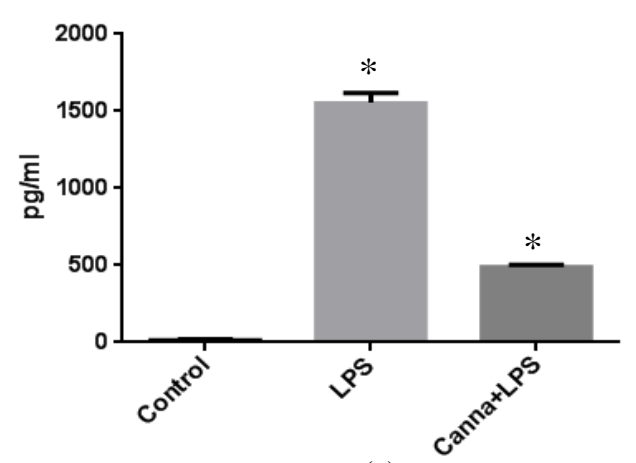

(a)

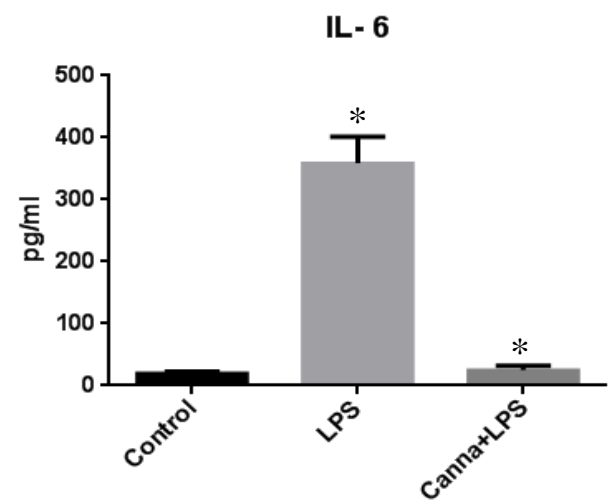

(b)

Figure 7. Cytokines/chemokine: Dermal fibroblasts Treatment with Cannabis extract 24 h. Suppression of lipopolysaccharide (LPS)-stimulated accumulation of sentinel cytokines/chemokines by cannabis extract in dermal fibroblasts. Dermal fibroblasts were grown in 12 well plates (Corning) to produce confluent monolayers in DMEM with $5 \%$ fetal bovine serum. LPS was added to the culture media at $1 \mu \mathrm{g} / \mathrm{ml}$ for $24 \mathrm{~h} \pm 45$ or $20 \mu \mathrm{g} / \mathrm{ml} \mathrm{CBD}$ cannabis extract. Accumulation of IL-6 (a) and IL-8 (b), was determined from conditioned media by enzyme-linked immunosorbent assay. Cytokine/chemokine accumulation was compared with levels of LPS-stimulated samples, expressed as $\mathrm{pg} / \mathrm{ml},{ }^{*} \mathrm{p}<0.001$.

cells were seeded onto non-adherent 6-well plates and treated with either cannabis extract or vehicle for 14 days. Images of the prostaspheres were captured under the microscope. The number of prostaspheres formed was counted at the end of 14 days. The cannabis extract treatment $(20 \mu \mathrm{g} / \mathrm{ml} \mathrm{CBD})$ efficiently suppressed the spheroid formation ability of LNCaP cells. LNCaP cells spheroids in the vehicle measured $150 \mu \mathrm{m}$ to $250 \mu \mathrm{m}$ diameter after 14 days. The cells treated with cannabis extract did not form spheroid and appeared as single or group of 2 or 4 cells after 14 days (Figure 8(a) \& Figure 8(b)).

\section{Discussion}

Prostate cancer is the most frequently diagnosed cancer in western males [35]. The progression of most of the cancers including prostate cancer may be a result of defects in cell cycle and apoptotic machinery. Thus, the agents which can modulate apoptosis in cancer cells may be useful in the management and therapy of cancer. Hence, there is a need to develop novel targets and mechanism-based agents for the management of prostate cancer. One of the most exciting and promising areas of current cannabinoid research is the ability of these compounds to control the cell survival/death decision [7]. In this study, we found that compared with PrEC cells, the expression levels of both cannabinoid receptors CB1 and CB2 were significantly higher in human prostate cells LNCaP, DU145, PC3 (Figure 2). These data suggest that CB1 and CB2 receptors could be targets for treatment options for prostate cancer. We also found that cannabis extract treatment of LNCaP and PC3 cells resulted in a decrease of cell viability as determined by MTS assay at varying doses (Figure 8(c) \& Figure 8(d)), suggesting the involvement of both CB1 and CB2 in the anti-proliferative action of cannabinoids. Treatment of LNCaP cells with varying doses of cannabis extract resulted in down regulation of mRNA expression of CB1 and CB2 implicating cytopathic effect of cannabis extract on PCa cells (Figure 4). Apoptosis is a physiological and discrete way of cell death and is regarded to be an ideal way of cell elimination. In this study, we also observed an increase in apoptosis of LNCaP cells by treatment with cannabis extract and this was confirmed by flow cytometry (Figure 6(a) \& Figure 6(b)). The observation could be useful for the management of human prostate cancer.

Androgens are essential for the growth, differentiation, and functioning of the prostate as well as in increasing prostate cancer development [36]. The over expression of androgen receptor in prostate cancer may promote cell growth. Hence, elimination or reducing the androgen receptor in prostate cancer should help in treating this neoplastic disease. We further studied the effect of cannabis extract on androgen receptor mRNA expression and its subsequent effect on PSA production. Our results indicate that cannabis extract treatment significantly decreases androgen receptor mRNA expression (Figure 5(a)) in LNCaP cells. PSA is an androgen receptor (AR)-regulated serine protease produced by prostate epithelial cells [37], and is the most widely employed 


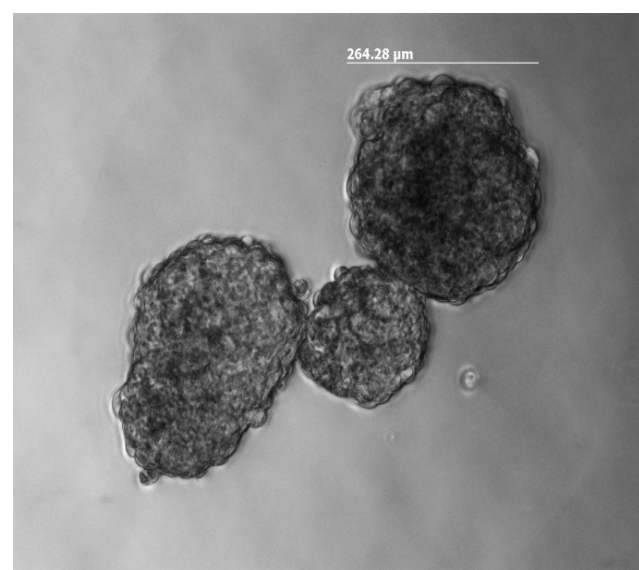

(a)

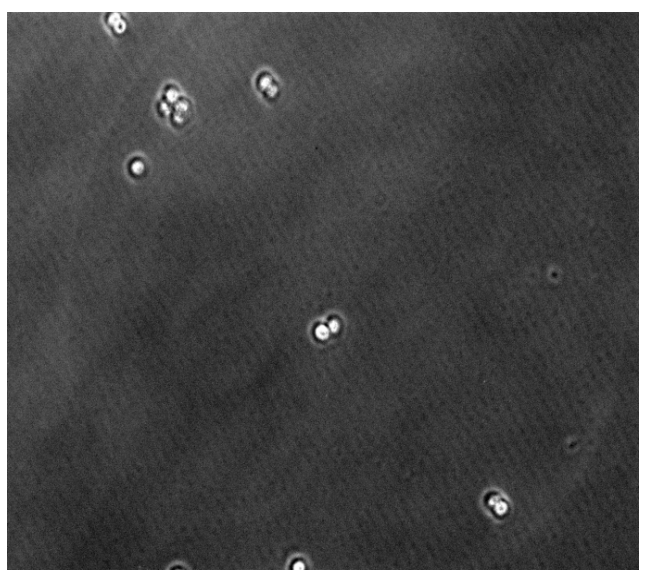

(b)

\begin{abstract}
Figure 8. Effect of cannabis extract on LNCaP prostaspheres formation: Spheroid formation assay was performed with cells treated with cannabis extract or vehicle. 500 LNCaP cells were seeded onto non-adherent 6 -well plates and treated with either cannabis extract or vehicle for 14 days. The number of prostaspheres formed was counted at the end of 14 days. (a) Typical LNCaP prostaspheres generated after 14 days and image of the prostaspheres was captured under microscope, 10× magnification. LNCaP prostaspheres in the vehicle measured $150 \mu \mathrm{m}$ to $264 \mu \mathrm{m}$ diameter after 14 days. (b) Note that prostaspheres are reduced to single or group of 4 cells in the cannabis extract treated group. The cannabis extract treatment efficiently suppresses the spheroid formation ability of LNCaP cells.
\end{abstract}

marker in the detection of early prostate cancer. Therefore, agents which could reduce PSA levels may have important clinical implications for prostate cancer. Earlier studies reported that PSA is primarily regulated by androgens [38]. Increased PSA level is used extensively as a biomarker of prostate diseases including prostatitis, benign prostatic hypertrophy, and prostate cancer. It is reported that in LNCaP cells, androgens regulate PSA glycoprotein expression and mRNA via androgen receptor [39]. Our studies show a significant decrease in intracellular mRNA (Figure 5(c)) as well as secreted levels of PSA (Figure 5(d)) by cannabis extract treatment of cells, suggesting that cannabinoid receptor agonists may be exploited to prevent prostate cancer progression.

VEGF is a ubiquitous cytokine that regulates embryonic vasculogenesis and angiogenesis. Normal prostate epithelium expresses low levels of VEGF, whereas increased levels are reported in prostate carcinoma [40]. Studies have shown that cannabinoid treatment markedly reduced the expression of VEGF in gliomas, the most potent proangiogenic factor and also of angiopoietin 2, which contributes to the angiogenic process by preventing vessel maturation [41]. Our results showed that treatment of LNCaP with cannabis extract inhibits VEGF mRNA expression in LNCaP cells (Figure 5(b)).

Chronic inflammation has been linked to various steps in tumor formation, including cellular transformation, proliferation, invasion, angiogenesis, and metastasis [42]. Among the inflammatory cytokines, interleukin 1 (IL-1), IL-6, IL-8, and IL-10 have been reported as present in the prostate cancer cells [43], indicating the significance of these inflammatory factors in prostate cancer progression. Therefore, controlling inappropriate inflammation would appear to be one strategy that might help control cancer progression. Prior to assessing anti-inflammatory properties of cannabis extract, the ability of LPS to induce secretion of key cytokine-related factors (IL-6 and IL-8) was assessed in dermal fibroblasts. After $24 \mathrm{~h}$ of LPS stimulation, dermal fibroblast conditioned media contained substantially elevated levels of cytokine IL-6 and chemokine IL-8 (Figure 7(a) \& Figure 7(b)). Our results show that accumulation of the indicated cytokines in conditioned media of dermal fibroblasts was significantly suppressed by cannabis extract treatment confirming potential anti-inflammatory property of the high CBD cannabis extract preparation that may be considered to target chronic inflammation in prostate cancer.

Prostate cancer cells are in general highly resistant to common chemotherapeutic agents and the presence of CSCs is suggested to contribute to chemo resistance. The ability to form spheres in non-adherent, serum free conditions is a key property of stem cells (Reynolds et al. 1992) [34]. In this study, prostate cancer cell line LNCaP was able to form spheroids in non-adherent culture, suggesting the presence of cancer stem-like cells within these cell lines. Because prostaspheres are enriched with CSCs [44], the inhibitory effect of cannabis ex- 
tract on prostasphere formation supports that high CBD and low THC cannabis extract may be a potent agent in targeting or eliminating prostate cancer stem-like cells in vitro (Figure 8).

Recently, cannabinoids have received considerable attention due to their diverse pharmacologic activities such as cell growth inhibition, anti-inflammatory effects, and tumor regression. Our results suggest that treatment of androgen-responsive human prostate carcinoma LNCaP cells resulted in a decrease in intracellular and secreted levels of PSA, with concomitant inhibition of androgen receptor, cell growth, and induction of apoptosis. The data also demonstrate that cannabis extract is capable of significantly suppressing the expression of specific pro-inflammatory cytokine/chemokine in human dermal fibroblast cells. The study explains usefulness of LPS-stimulated in vitro systems for the evaluation of the anti-inflammatory properties of plant extracts using this methodological approach [45] [46]. To conclude, the data presented in this paper provide further support for the concept that traditional medicines, such as cannabis, can be valuable additions to the modern therapeutic armamentarium, and non-habit-forming cannabinoid agonist(s) which lack psychotropic activity may be used for the management of prostate cancer.

\section{Conflict of Interest}

There is no conflict of interest to be declared.

\section{References}

[1] Gnanapragasam, V.J., Robinson, M.C., Marsh, C., Robson, C.N., Hamdy, F.C. and Leung, H.Y. (2003) FGF8 Isoform b Expression in Human Prostate Cancer. British Journal of Cancer, 88, 1432-1438. http://dx.doi.org/10.1038/sj.bjc.6600875

[2] Lara Jr., P.N., Twardowski, P. and Quinn, D.I. (2004) Angiogenesistargeted Therapies in Prostate Cancer. Clinical Prostate Cancer, 3, 165-173. http://dx.doi.org/10.3816/CGC.2004.n.027

[3] Petrylak, D.P., Tangen, C.M., Hussain, M.H., Lara Jr., P.N., Jones, J.A., Taplin, M.E., Burch, P.A., Berry, D., Moinpour, C., Kohli, M., Benson, M.C., Small, E.J., et al. (2004) Docetaxel and Estramustine Compared with Mitoxantrone and Prednisone for Advanced Refractory Prostate Cancer. The New England Journal of Medicine, 351, 1513-1520.

[4] Maitland, N.J. and Collins, A.T. (2008) Prostate Cancer Stem Cells: A New Target for Therapy. Journal of Clinical Oncology, 26, 2862-2870. http://dx.doi.org/10.1200/JCO.2007.15.1472

[5] Holtz, M., Forman, S.J. and Bhatia, R. (2007) Growth Factor Stimulation Reduces Residual Quiescent Chronic Myelogenous Leukemia Progenitors Remaining after Imatinib Treatment. The Journal of Cancer Research, 67, 1113-1120. http://dx.doi.org/10.1158/0008-5472.CAN-06-2014

[6] Lawson, D.A., Zong, Y., Memarzadeh, S., Xin, L., Huang, J. and Witte, O.N. (2010) Basal Epithelial Stem Cells Are Efficient Targets for Prostate Cancer Initiation. Proceedings of the National Academy of Sciences of the United States of America, 107, 2610-2615. http://dx.doi.org/10.1073/pnas.0913873107

[7] Guzman, M. (2003) Cannabinoids: Potential Anticancer Agents. Nature Reviews Cancer, 3, 745-755. http://dx.doi.org/10.1038/nrc1188

[8] Velasco, G., Galve-Roperh, I., Sanchez, C., Blazquez, C. and Guzman, M. (2004) Hypothesis: Cannabinoid Therapy for the Treatment of Gliomas. Neuropharmacology, 47, 315-323. http://dx.doi.org/10.1016/j.neuropharm.2004.04.016

[9] Sarkar, K.P., Obara, S., Nakata, M., Kitajima, I. and Maruyama, I. (2000) Anandamide Induces Apoptosis of PC-12 Cells: Involvement of Superoxide and Caspase-3. FEBS Letters, 472, 1039-1044.

[10] Maccarrone, M., Lorenzon, T., Bari, M., Melino, G. and Finazzi-Agro, A. (2000) Anandamide Induces Apoptosis in Human Cells via Vanilloid Receptors. Evidence for a Protective Role of Cannabinoid Receptors. The Journal of Biological Chemistry, 275, 31938-31945. http://dx.doi.org/10.1074/jbc.M005722200

[11] Chan, G.C., Hinds, T.R., Impey, S. and Storm, D.R. (1998) Hippocampal Neurotoxicity of D9 Tetrahydrocannabinol. The Journal of Neuroscience, 18, 5322-5332.

[12] Guzman, M., Sanchez, C. and Galve-Roperh, I. (2001) Control of the Cell Survival/Death Decision by Cannabinoids. Journal of Molecular Medicine, 78, 613-625. http://dx.doi.org/10.1007/s001090000177

[13] De Petrocellis, L., Ligresti, A., SchianoMoriello, A., Iappelli, M., Verde, R., Stott, C.G., Cristino, L., Orlando, P. and Di Marzo, V. (2013) Non-THC Cannabinoids Inhibit Prostate Carcinoma Growth in Vitro and in Vivo: Pro-Apoptotic Effects and Underlying Mechanisms. British Journal of Pharmacology, 168, 79-102. http://dx.doi.org/10.1111/j.1476-5381.2012.02027.x

[14] Sreevalsan, S., Joseph, S., Jutooru, I., Chadalapaka, G. and Safe, S.H. (2011) Induction of Apoptosis by Cannabinoids in Prostate and Colon Cancer Cells Is Phosphatase Dependent. Anticancer Research, 31, 3799-3807. 
[15] Hornby, A.P. and Sharma, M. (2010) Standardized Cannabis in Multiple Sclerosis: A Case Report. Cases Journal, 3, 1-5.

[16] Hornby, A.P., Sharma, M. and Stegman, B. (2009) Standardized Natural Product Cannabis in Pain Management and Observations at a Canadian Compassion Society: A Case Report. Cases Journal, 2, 1-3.

[17] Sharma, M. (2012) Cannabis Responsive Head Injury Induced Multiple Disabilities: A Case Report. Pharmacology \& Pharmacy, 3, 58-61.

[18] Robson, P. (2005) Human Studies of Cannabinoids and Medicinal Cannabis. Handbook of Experimental Pharmacology, 168, 719-756.

[19] Kogan, N.M. (2005) Cannabinoids and Cancer. Mini-Reviews in Medicinal Chemistry, 5, 941-952. http://dx.doi.org/10.2174/138955705774329555

[20] Melck, D., De Petrocellis, L., Orlando, P., Bisogno, T., Laezza, C., Bifulco, M. and Di Marzo, V. (2000) Suppression of Nerve Growth Factor Trk Receptors and Prolactin Receptors by Endocannabinoids Leads to Inhibition of Human Breast and Prostate Cancer Cell Proliferation. Endocrinology, 141, 118-126.

[21] Casanova, M.L., Blázquez, C., Martínez-Palacio, J., Villanueva, C., Fernández-Aceñero, M.J., Huffman, J.W., Jorcano, J.L. and Guzmán, M. (2003) Inhibition of Skin Tumor Growth and Angiogenesis in Vivo by Activation of Cannabinoid Receptors. The Journal of Clinical Investigation, 111, 43-50. http://dx.doi.org/10.1172/JCI200316116

[22] McKallip, R.J., Nagarkatti, M. and Nagarkatti, P.S. (2005) Delta-9-Tetrahydrocannabinol Enhances Breast Cancer Growth and Metastasis by Suppression of the Antitumor Immune Response. The Journal of Immunology, 174, 32813289. http://dx.doi.org/10.4049/jimmunol.174.6.3281

[23] Pertwee, R.G. (1997) Pharmacology of Cannabinoid $\mathrm{CB}_{1}$ and $\mathrm{CB}_{2}$ Receptors. Pharmacology \& Therapeutics, 74, 129180. http://dx.doi.org/10.1016/S0163-7258(97)82001-3

[24] Walsh, D., Nelson, K.A. and Mahmoud, F.A. (2003) Established and Potential Therapeutic Applications of Cannabinoids in Oncology. Support Care Cancer, 11,137-143.

[25] Mechoulam, R., Parker, L.A. and Gallily, R. (2002) Cannabidiol: An Overview of Some Pharmacological Aspects. The Journal of Clinical Pharmacology, 42, 11S-19S. http://dx.doi.org/10.1002/j.1552-4604.2002.tb05998.x

[26] Pertwee, R.G. (2004) The Pharmacology and Therapeutic Potential of Cannabidiol. In: Di Marzo, V., Ed., Cannabinoids, Kluwer Academic/Plenum Publishers, New York, 32-83.

[27] Russo, E. and Guy, G.W. (2006) A Tale of Two Cannabinoids: The Therapeutic Rationale for Combining Tetrahydrocannabinol and Cannabidiol. Medical Hypotheses, 66, 234-246. http://dx.doi.org/10.1016/j.mehy.2005.08.026

[28] Ilan, A.B., Gevins, A., Coleman, M., ElSohly, M.A. and de Wit, H. (2005) Neurophysiological and Subjective Profile of Marijuana with Varying Concentrations of Cannabinoids. Behavioural Pharmacology, 16, 487-496. http://dx.doi.org/10.1097/00008877-200509000-00023

[29] Colasanti, B.K. (1990) A Comparison of the Ocular and Central Effects of Delta 9-Tetrahydrocannabinol and Cannabigerol. Journal of Ocular Pharmacology and Therapeutics, 16, 259-269. http://dx.doi.org/10.1089/jop.1990.6.259

[30] Schmittgen, T.D. and Livak, K.J. (2008) Analyzing Real-Time PCR Data by the Comparative $\mathrm{C}_{\mathrm{T}}$ Method. Nature Protocols, 3, 1101-1108. http://dx.doi.org/10.1038/nprot.2008.73

[31] Naz, R.K. and Herness, E.A. (2001) Prostate-Specific Genes: Present Status and Future Direction. Frontiers in Bioscience, 6, 1083-1088.

[32] Stamey, T.A., Yang, N., Hay, A.R., McNeal, J.E., Freiha, F.S. and Redwine, E. (1987) Prostate-Specific Antigen as a Serum Marker for Adenocarcinoma of the Prostate. The New England Journal of Medicine, 317, 909-916. http://dx.doi.org/10.1056/NEJM198710083171501

[33] Joseph, I.B., Nelson, J.B., Denmeade, S.R. and Isaacs, J.T. (1997) Androgens Regulate Vascular Endothelial Growth Factor Content in Normal and Malignant Prostatic Tissue. Clinical Cancer Research, 12, 2507-2511.

[34] Reynolds, B.A. and Weiss, S. (1992) Generation of Neurons and Astrocytes from Isolated Cells of the Adult Mammalian Central Nervous System. Science, 255, 1707-1710. http://dx.doi.org/10.1126/science.1553558

[35] Amanatullah, D.F., Reutens, A.T., Zafonte, B.T., Fu, M., Mani, S. and Pestell, R.G. (2000) Cell-Cycle Dysregulation and the Molecular Mechanisms of Prostate Cancer. Frontiers in Bioscience, 5, D372-D390.

[36] Koivisto, P., Kolmer, M., Visakorpi, T. and Kallioniemi, O.P. (1998) Androgen Receptor Gene and Hormonal Therapy Failure of Prostate Cancer. American Journal of Pathology, 152, 1-9.

[37] Balk, S.P., Ko, Y.J. and Bubley, G.J. (2003) Biology of Prostate-Specific Antigen. Journal of Clinical Oncology, 21, 383-391. http://dx.doi.org/10.1200/JCO.2003.02.083

[38] Montgomery, B.T., Young, C.Y., Bilhartz, D.L., Andrews, P.E., Prescott, J.L., Thompson, N.F., Prescott, J.L. and Tindall, D.J. (1992) Hormonal Regulation of Prostate-Specific Antigen (PSA) Glycoprotein in the Human Prostatic 
Adenocarcinoma Cell Line, LNCaP. The Prostate, 21, 63-73. http://dx.doi.org/10.1002/pros.2990210107

[39] Lee, C., Sutkowski, D.M., Sensibar, J.A., Zelner, D., Kim, I., Amsel, I., et al. (1995) Regulation of Proliferation and Production of Prostate-Specific Antigen in Androgen-Sensitive Prostatic Cancer Cells, LNCaP, by Dihydrotestosterone. Endocrinology, 136, 796-803.

[40] Mazzucchelli, R., Montironi, R., Santinelli, A., Lucarini, G., Pugnaloni, A. and Biagini, G. (2000) Vascular Endothelial Growth Factor Expression and Capillary Architecture in High Grade PIN and Prostate Cancer in Untreated and Androgen-Ablated Patients. The Prostate, 45, 72-79.

[41] Blázquez, C., Casanova, M.L., Planas, A., Del Pulgar, T.G., Villanueva, C., Fernández-Aceñero, M.J., et al. (2003) Inhibition of Tumor Angiogenesis by Cannabinoids. The FASEB Journal, 17, 529-531.

[42] Mantovani, A. (2007) Cancer: An Infernal Triangle. Nature, 436, 547-548. http://dx.doi.org/10.1038/448547a

[43] van der Poel, H.G. (2007) Molecular Markers in the Diagnosis of Prostate Cancer. Critical Reviews in Oncology/Hematology, 61, 104-139. http://dx.doi.org/10.1016/j.critrevonc.2006.07.003

[44] Dubrovska, A., Kim, S., Salamone, R.J., Walker, J.R., Maira, S.M., Garcia-Echeverria, C., Schultz, P.G. and Reddy, V.A. (2009) The Role of PTEN/Akt/PI3K Signaling in the Maintenance and Viability of Prostate Cancer Stem-Like Cell Populations. Proceedings of the National Academy of Sciences of the United States of America, 106, 268-273. http://dx.doi.org/10.1073/pnas.0810956106

[45] Magni, P., Ruscica, M., Dozio, E., Rizzi, E., Beretta, G. and Facino, R.M. (2012) Parthenolide Inhibits the LPS-Induced Secretion of IL-6 and TNF- $\alpha$ and NF-кB Nuclear Translocation in BV-2 Microglia. Phytotherapy Research, 26, 1405-1409. http://dx.doi.org/10.1002/ptr.3732

[46] Yan, Y.Y., Wang, Y.W., Chen, S.L., Zhuang, S.R. and Wang, C.K. (2013) Anti-Inflammatory Effects of Phenolic Crude Extracts from Five Fractions of Corchorus olitorius L. Food Chemistry, 138, 1008-1014.

http://dx.doi.org/10.1016/j.foodchem.2012.10.052 
Scientific Research Publishing (SCIRP) is one of the largest Open Access journal publishers. It is currently publishing more than 200 open access, online, peer-reviewed journals covering a wide range of academic disciplines. SCIRP serves the worldwide academic communities and contributes to the progress and application of science with its publication.

Other selected journals from SCIRP are listed as below. Submit your manuscript to us via either submit@scirp.org or Online Submission Portal.
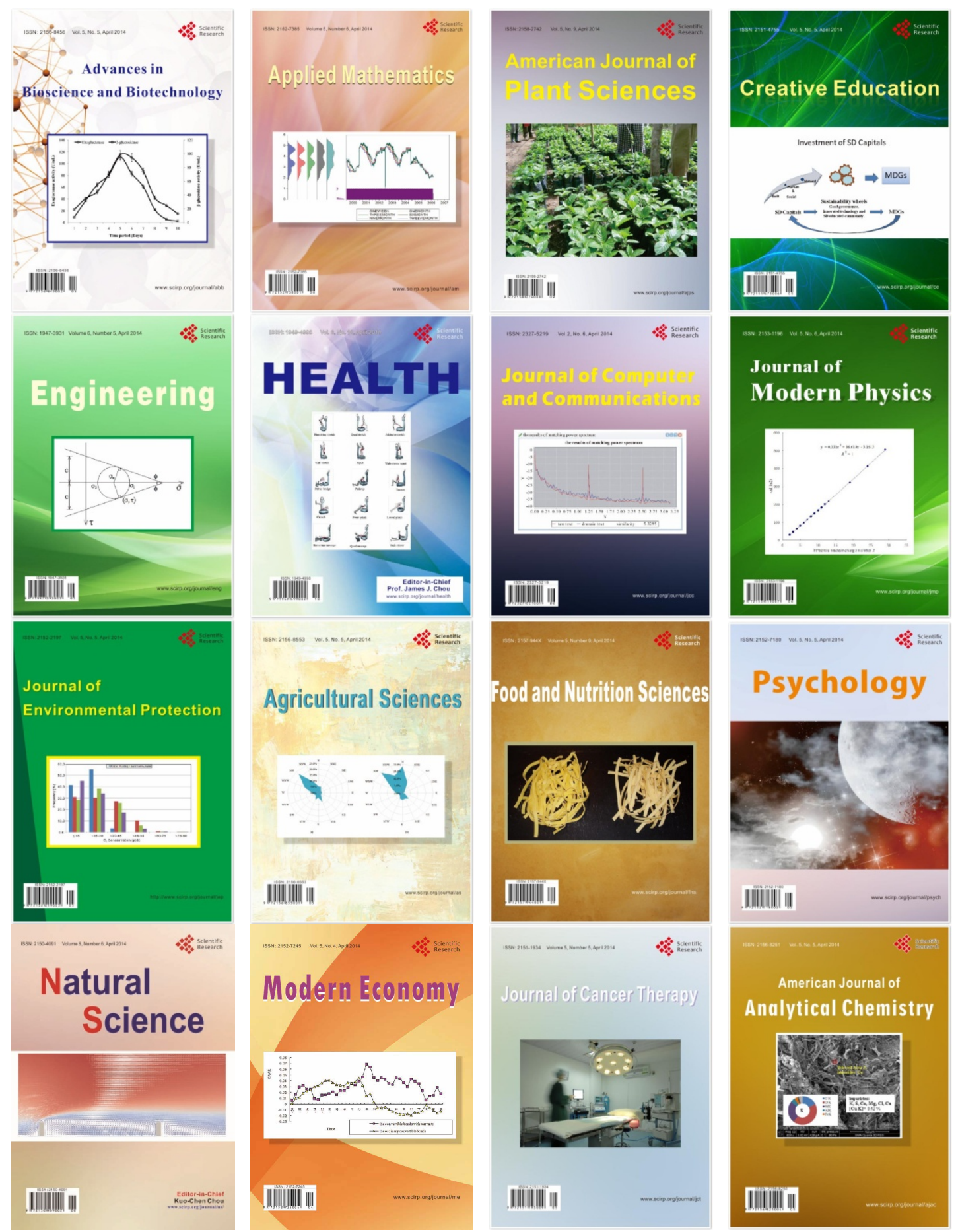